Language Revitalisation in Gaelic Scotland 
Do Fhinn agus do Chiorstaidh 


\section{LANGUAGE REVITALISATION IN GAELIC SCOTLAND}

Linguistic Practice and Ideology

Stuart Dunmore 
Edinburgh University Press is one of the leading university presses in the UK. We publish academic books and journals in our selected subject areas across the humanities and social sciences, combining cutting-edge scholarship with high editorial and production values to produce academic works of lasting importance. For more information visit our website: edinburghuniversitypress.com

(C) Stuart S. Dunmore, 2019

Edinburgh University Press Ltd

The Tun - Holyrood Road, 12(2f) Jackson's Entry, Edinburgh EH8 8PJ

Typeset in 10/12 Ehrhardt by

Servis Filmsetting Ltd, Stockport, Cheshire, and printed and bound in Great Britain.

A CIP record for this book is available from the British Library

ISBN 9781474443111 (hardback)

ISBN 9781474443128 (webready PDF)

ISBN 9781474443135 (epub)

The right of Stuart S. Dunmore to be identified as the author of this work has been asserted in accordance with the Copyright, Designs and Patents Act 1988, and the Copyright and Related Rights Regulations 2003 (SI No. 2498). 